\title{
KONSENTRASI DAN INTERVAL APLIKASI PUPUK ORGANIK CAIR Amazing Bio-Growth TERHADAP KOMPONEN HASIL TANAMAN KACANG HIJAU (Phaseolus radiate L.) VARIETAS LOKAL SABU
}

\author{
Maria Klara Salli dan Masria
}

Jurusan Manajemen Pertanian Lahan Kering, Politeknik Pertanian Negeri Kupang, J. Prof. Dr. Herman Yohanes Lasiana Kupang P.O.Box. 1152, Kupang 85011

Korespondensi: maria.klara.salli@gmail.com

\begin{abstract}
The purpose of this study was to obtain the best concentration and interval of application of POC ABG to increase the yield of local varieties of mung bean Sabu.RBD with two factors was used in this study namely, factor 1(concentration): 2, 4, 6, and $8 \mathrm{ml} \mathrm{LOF/liter} \mathrm{of} \mathrm{water;} \mathrm{factor} 2$ (interval): 7 and 14 days once. Data were analyzed using ANOVA and further test using DMRT 5\%.The results showed that there was no effect of POC ABG treatment on the number of seeds/pods and the weight of 100 seeds. POC ABG concentrations of 2 and $4 \mathrm{ml}$ liter of water and application intervals of 7 days gave the highest seed yields per plot $(240.73$ grams and 238.84 grams) and 240.66 grams. The interaction of treatment $4 \mathrm{ml} /$ liter of water and application interval of 7 days gave the number of pods planted (15.22) and the highest seed yield (9.63 grams).
\end{abstract}

Key Words: Concentration, interval, $A B G$, mung beans local var Sabu

\section{PENDAHULUAN}

Produktivitas kacang hijau di Nusa Tenggara Timur (NTT) meningkat dari tahun 2017 hingga tahun 2020. Data Dirjen Tanaman Pangan, 2020 menunjukkan produktivitas kacang hijau di NTT mencapai 2.27 ton/ha sedangkan rata-rata produktivitas nasional mencapai 1.21 ton/ha. Ditingkat petani, rata-rata produktivitas baru mencapai 0,9 ton/ha. Sedangkan dari hasil percobaan dapat mencapai 1,60 ton/ha. (Aziz dan Bakar2015). Rendahnya hasil kacang hijau di tingkat petani antara lain disebabkan oleh penggunaan varetas lokal dan praktek budidaya yang kurang optimal (Murdolelono, 2011).

Peningkatan produktivitas kacang-kacangan dapat dilakukan melalui peningkatan produksi dan luas tanam. Peningkatan produksi kacang hijau antara lain dapat dilakukan dengan cara menggunakan varietas unggul serta penyediaan teknologi inovatif dan strategis, seperi pupuk organik, pupuk hayati dan biopestisida. (Muchlis dan Marwoto, 2014). Walaupun demikian, setiap 
varietas mempunyai spesifikasi lokasi adaptasi, termasuk pada daerah lahan kering beriklim kering seperti di daerah NTT.

Varietas lokal Sabu merupakan kacang hijau dari daerah Sabu Raijua namun produktivitas nya masih rendah yaitu 0,73 ton/ha (Lidjang, dkk, 2012). Kacang hijau pada lahan kering di NTT secara tradisional ditanam secara tumpangsari dengan jagung, jarak tanam tidak teratur dan tanpa pemupukan. Sehingga diperlukan masukan teknologi budidaya untuk meningkatkan produksi. Salah satu teknologi itu adalah pemupukan tanaman. Penggunaan pupuk anorganik memberikan dampak yang positif dan negatif. Penggunaan dalam waktu yang lama akan mengakibatkan dampak negatif terhadap ekosistem tanah (Sutanto, 2002) serta harga pupuk anorganik selalu meningkat dan sering langka di pasaran. Banyak pupuk organik cair (POC) yang beredar di masyarakat, baik itu buatan sendiri atau buatan pabrik. Untuk itu perlu di lakukan penelitian meliputi dosis dan interval penyemprotan, POC Amazing Bio-growth, sehingga sebagai informasi yang baik untuk aplikasi POC di lahan petani.

\section{METODE PENELITIAN}

\section{Rancangan Penelitian}

Penelitian ini menggunakan Rancangan Acak Kelompok pola factorial dengan 2 faktor penelitian yaitu konsentrasi POC ABG (K) dengan 4 level perlakuan: 2ml/liter air (K1), 4 ml/liter air (K2), 6 ml/liter air (K3) dan 8 ml/liter air (K4), dan interval aplikasi (I) dengan 2 level perlakuan yaitu: 7 hari sekali (I1) dan 14 hari sekali (I2). Penempatan perlakuan secara acak dengan 3 ulangan.

\section{Teknik Pengumpulan Data dan Analisis Data}

Pengumpulan data di lakukan pada tanaman sampel dan variabel penelitiannya berupa komponen hasil, yakni :

a. Jumlah polong per tanaman)

b. Jumlah biji/polong

c. Berat/bobot 100 biji

d. Hasil biji pertanaman

e. Hasil biji/petak dan

f. Data penunjang berupa hasil analisis tanah awal 


\section{Penentuan Lokasi dan Waktu Penelitian}

Penelitian dilakukan di Laboratorium Lapang Sistem Usahatani Terpadu Jurusan Manajemen Pertanian Lahan Kering Politeknik Pertanian Negeri Kupang, pada bulan April sampai dengan Oktober 2021.

\section{Teknik Analisis Data}

Data di analisis dengan analisis Varian, dengan uji lanjut menggunakan Uji DMRT.

\section{HASIL DAN PEMBAHASAN}

\section{Hasil Analisis Tanah}

Hasil analisis tanah menunjukkan sifat awal tanah penelitian adalah tekstur tanah lempung berliat, PH (H2O) 6,0, C- organic 2.12\%, KTK $19.20 \mathrm{cmol}$ (+) kg-1( sedang), Kejenuhan basa 48\% (sdang), Nitrogen 0.20\% dan P205 10.21 ppm.

\section{Jumlah Polong Pertanaman}

Hasil analisis varians terhadap jumlah polong pertanaman kacang hijau varietas lokal Sabu menunjukkan pengaruh yang sangat nyata akibat interval aplikasi POC ABG, serta adanya interaksi antara kedua perlakuan tersebut. Hasil uji DMRT terhadap rerata jumlah polong per tanaman kacang hijau varietas lokal Sabu disajikan pada Tabel 1.

Tabel 1. Rerata Jumlah Polong per tanaman Kacang Hijau Varietas Lokal Sabu akibat perlakuan Konsentrasi dan Interval Aplikasi POC ABG

\begin{tabular}{|c|c|c|c|c|c|}
\hline \multirow{2}{*}{$\begin{array}{c}\text { Interval } \\
\text { Aplikasi (I) }\end{array}$} & \multicolumn{4}{|c|}{ Konsentrasi POC ABG } & \multirow[t]{2}{*}{ Rerata } \\
\hline & $\mathbf{K} 1$ & $\mathbf{K} 2$ & K3 & K4 & \\
\hline I1 & $12.42 \mathrm{bcd}$ & $15.22 \mathrm{~d}$ & $13.13 \mathrm{bcd}$ & $12.20 \mathrm{abcd}$ & $13.24 \mathrm{~b}$ \\
\hline $\mathrm{I} 2$ & $13.92 \mathrm{~cd}$ & $8.65 \mathrm{a}$ & $9.34 \mathrm{ab}$ & $10.54 \mathrm{abc}$ & $10.61 \mathrm{a}$ \\
\hline Rerata & 13.17 & 11.94 & 11.23 & 11.37 & \\
\hline
\end{tabular}

Keterangan: Angka yang diikuti huruf yang sama berarti tidak berbeda nyata pada taraf $5 \%$ Uji Jarak Berganda Duncan.

Tabel 1 menunjukkan bahwa jumlah polong pertanaman terbanyak (15.22) terdapat pada perlakuan konsentrasi POC ABG $4 \mathrm{ml} /$ liter air dengan interval 
pemberian 7 hari sekali (perlakuan K2I1) yang tidak berbeda nyata dengan perlakuan K1I1, K1I2 dan K4I1 tetapi berbeda nyata dengan perlakuan K2I2, K3I2 dan K4I2. Jumlah polong pertanaman terkecil (8.65) ditunjukkan oleh perlakuan konsentrasi POC ABG $3 \mathrm{ml} /$ liter air dengan interval pemberian 14 hari sekali (K3I2), yang tidak berbeda nyata dengan perlakuan K4I1, K3I2 dan K4I2.

\section{Jumlah Biji Per Polong}

Hasil analisis varians terhadap jumlah biji/polong kacang hijau varietas lokal Sabu menunjukkan tidak ada pengaruh yang di akibatkan oleh konsentrasi dan interval aplikasi POC Amazing-Bio Growth. Hasil uji DMRT terhadap rerata jumlah biji perpolong tanaman kacang hijau varietas lokal Sabu disajikan pada Tabel 2.

Tabel 2. Rerata Jumlah Biji Perpolong tanaman Kacang Hijau Varietas Lokal Sabu akibat perlakuan Konsentrasi dan Interval Aplikasi POC ABG

\begin{tabular}{cccccc}
\hline Interval & \multicolumn{5}{c}{ Konsentrasi POC ABG } \\
Aplikasi (I) & K1 & K2 & K3 & K4 & Rerata \\
\hline I1 & 9.91 & 8.63 & 9.08 & 8.96 & 9.15 \\
\hline I2 & 8.63 & 9.50 & 9.37 & 9.40 & 9.23 \\
\hline Rerata & 9.27 & 9.07 & 9.23 & 9.18 & \\
\hline
\end{tabular}

Keterangan: Angka yang diikuti huruf yang sama berarti tidak berbeda nyata pada taraf $5 \%$ Uji Jarak Berganda Duncan.

Tabel 2. Menunjukkan bahwa jumlah biji perpolong tanaman kacang hijau varietas lokal Sabu berkisar 8.63 - 9.91 .

\section{Berat 100 Butir}

Hasil analisis varians terhadap berat 100 butir biji kacang hijau varietas lokal Sabu menunjukkan tidak ada pengaruh antara perlakuan. Yang di cobakan. Hasil uji DMRT terhadap rerata berat/bobot 100 butir biji kacang hijau varietas lokal Sabu disajikan pada Tabel 3.

Tabel 3. Rerata Berat 100 butir (Gram) Tanaman Kacang Hijau Varietas Lokal Sabu akibat perlakuan Konsentrasi dan Interval Aplikasi POC ABG

\begin{tabular}{cccccc}
\hline $\begin{array}{c}\text { Interval Aplikasi } \\
\text { (I) }\end{array}$ & $\mathbf{K 1}$ & Konsentrasi POC ABG & Rerata \\
\hline I1 & 6.18 & 6.74 & 6.72 & 7.13 & 6.69 \\
\hline I2 & 6.61 & 6.55 & 6.70 & 6.89 & 6.69 \\
\hline Rerata & 6.40 & 6.65 & 6.71 & 7.01 & \\
\hline
\end{tabular}

Keterangan: Angka yang diikuti huruf yang sama berarti tidak berbeda nyata pada taraf $5 \%$ Uji Jarak Berganda Duncan. 
Tabel 3 menunjukkan bahwa rerata berat 100 butir biji kacang hijau varietas lokal Sabu berkisar $6.18-7.13$ gram.

\section{Hasil Biji Per Tanaman}

Hasil analisis varians terhadap Hasil biji per tanaman kacang hijau varietas lokal Sabu menunjukkan ada pengaruh nyata akibat interval aplikasi POC Amazing Bio-Growth dan pengaruh interaksi antara konsentrasi dan interval aplikasi POC ABG tersebut. Hasil uji DMRT terhadap rerata hasil biji pertanaman kacang hijau varietas lokal Sabu disajikan pada Tabel 4.

Tabel 4. Rerata Hasil Biji Pertanaman (Gram) Kacang Hijau Varietas Lokal Sabu akibat perlakuan Konsentrasi dan Interval Aplikasi POC ABG

\begin{tabular}{|c|c|c|c|c|c|}
\hline \multirow{2}{*}{$\begin{array}{l}\text { Interval Aplikasi } \\
\text { (I) }\end{array}$} & \multicolumn{4}{|c|}{ Konsentrasi POC ABG } & \multirow[t]{2}{*}{ Rerata } \\
\hline & $\mathbf{K 1}$ & $\mathbf{K 2}$ & K3 & K4 & \\
\hline I1 & $7.18 \mathrm{abc}$ & $9.63 \mathrm{c}$ & $7.14 \mathrm{abc}$ & $6.98 \mathrm{abc}$ & $7.52 \mathrm{~b}$ \\
\hline $\mathrm{I} 2$ & $7.87 \mathrm{abc}$ & $6.15 \mathrm{ab}$ & $5.53 \mathrm{a}$ & $6.82 \mathrm{abc}$ & $6.59 \mathrm{a}$ \\
\hline Rerata & 7.52 & 7.46 & 6.34 & 6.90 & \\
\hline
\end{tabular}

Tabel 4 menunjukkan bahwa hasil biji pertanaman tertinggi terdapat pada perlakuan K2I1 yaitu konsentrasi POC ABG $4 \mathrm{ml}$ dengan interval pemberian 7 hari sekali (9.63 gram) yang tidak berbeda nyata dengan perlakuan K1I1, K1I2, K3I1, K4I1 dan K4I2. Hasil biji terendah (5.53 gram) terdapat pada perlakuan konsentrasi POC ABG 6 ml dengan interval aplikasi 14 hari sekali (K3I2) dan tidak berbeda dengan perlakuan lainnya kecuali perlakuan K2I1.

\section{Hasil Biji per Petak}

Hasil analisis varians terhadap Hasil biji per petak kacang hijau varietas lokal Sabu menunjukkan tidak ada pengaruh nyata akibat konsentrasi dan interval aplikasi POC Amazing Bio-Growth. Pengaruh tersebut di tunjukkan oleh pengaruh tunggal dari perlakuan konsentrasi dan interval aplikasi POC ABG. Hasil uji DMRT terhadap rerata hasil biji kacang hijau varietas lokal Sabu per petak percobaan disajikan pada Tabel 5. 
Tabel 5. Rerata Hasil Biji Perpetak (Gram) Tanaman Kacang Hijau Varietas Lokal Sabu akibat perlakuan Konsentrasi dan Interval Aplikasi POC ABG

\begin{tabular}{cccccc}
\hline $\begin{array}{c}\text { Interval } \\
\text { Aplikasi (I) }\end{array}$ & $\mathbf{K 1}$ & \multicolumn{2}{c}{ Konsentrasi POC ABG } & \multicolumn{2}{c}{ Rerata } \\
\hline $\mathrm{I} 1$ & 229.73 & 280.98 & 228.53 & 223.38 & $240.66 \mathrm{~b}$ \\
\hline $\mathrm{I} 2$ & 251.73 & 196.71 & 177.07 & 169.80 & $198.83 \mathrm{a}$ \\
\hline Rerata & $240.73 \mathrm{~b}$ & $238.84 \mathrm{~b}$ & $202.80 \mathrm{ab}$ & $196.59 \mathrm{a}$ & \\
\hline
\end{tabular}

Keterangan: angka yang diikuti huruf yang sama berarti tidak berbeda nyata pada taraf 5\% Uji Jarak Berganda Duncan.

Tabel 5 menunjukkan bahwa hasil biji pertanaman tertinggi terdapat pada perlakuan K1 (konsentrasi POC ABG 2 ml/liter air) yang tidak berbeda dengan perlakuan K2 (4 ml/liter air). Hasil biji/petak terendah pada perlakuan K4 (8 $\mathrm{ml} /$ liter air) yang tidak berbeda nyata dengan perlakuan $\mathrm{K} 3$ (6 ml/liter air).

\section{Pembahasan}

Interaksi antara konsentrasidan aplikasi POC ABG berpengaruh sangat nyata terhadap jumlah polong pertanaman dan hasil biji pertanaman kacang hijau varietas Lokal Sabu serta tidak berbengaruh terhadap jumlah biji per polong dan berat 100 butir biji. Pengaruh tunggal dari konsentrasi dan interval aplikasi ditunjukkan terhadap hasil biji per petak percobaan.

Pupuk ABG yang diberikan pada interval 7 hari sekali berupa ABG daun yang di berikan selama 3 kali yaitu umur tanaman 2 MST sampai dengan umur tanaman 28 MST atau pada fase vegetative dan di lanjutkan dengan dua kali pemberian ABG bunga dan buah pada umur 5 dan 6 MST atau pada fase generative. Sedangkan untuk aplikasi 14 hari sekali hanya di berikan sebanyak 3 kali yang terdiri dari 2 kali pemberian ABG daun dan satu kali pemberian ABG buah.

Pupuk ABG mengandung hara makro, hara mikro, C-organik, senyawa bioaktif seperti auksin, citokinin, giberellin dan mikroba yang menguntungkan tanaman seperti mikroba pengurai, penambat $\mathrm{N}$ dan pelarut fosfat (Nasution A.S.2015). Kandungan unsur hara makro khususnya unsur P (6\% P2O5) dan unsur hara mikro yang terdapat dalam pupuk cair ABG dapat menunjang pembentukan biji. Unsur Phosphor berperanan dalam pembentukan bunga, buah dan biji Selanjutnya Adanya mikroba pelarut fosfat dalam pupuk cair ABG dapat mempengaruhi serapan $\mathrm{P}$ dan meningkatkan peranan $\mathrm{P}$ pada tanaman kacang hijau. Hal ini dibuktikan dengan jumlah polong pertanaman 15.22 
polong dan hasil biji per tanaman tertinggi yaitu 9.63 gram ditunjukkan oleh konsentrasi $4 \mathrm{ml} /$ liter air dengan interval aplikasi 7 hari sekali. Serapan P yang baik berpengaruh terhadap suplai karbohidrat hasil fotosintesis yang berperanan dalam pengisian buah (Theodore, dkk, 1993).

Jumlah biji perpolong dan berat 100 butir biji kacang hijau varietas lokal Sabu tidak di pengaruhi oleh konsentrasi dan interval aplikasi POC ABG. Hal ini disebabkan karena produksi tanaman selain dipengaruhi faktor luar juga faktor dalam atau faktor genetic. Faktor-faktor yang mempengaruhi berat biji tanaman kacang hijau diantaranya ditentukan oleh faktor genetik, praktek agronomi yang baik, dan kondisi lingkungan (Ali et al 2010).

Hasil biji per tanaman kacang hijau varietas lokal Sabu tertinggi pada perlakuan POC ABG $4 \mathrm{ml}$ dengan interval aplikasi 7 hari sekaliyang berbeda dengan perlakuan $4 \mathrm{ml}$ dengan interval 14 hari. Sedangkan hasil biji perpetak tertinggi pada konsentrasi $2 \mathrm{ml}$ /liter air yang tidak berbeda dengan konsentrasi 4 $\mathrm{ml} /$ liter air. Hal ini disebabkan karena ketersediaan $\mathrm{P}$ di dalam tanah. Ketersediaan $\mathrm{P}$ didalam tanah dipengaruhi oleh beberapa factor, diantaranya $\mathrm{pH}$ tanah, tekstur, Kapasitas tukar kation dan konsentrasi larutan di dalam tanah. Unsur $\mathrm{P}$ adalah unsur yang diserap tanaman melalui proses difusi, sangat immobile dibandingkan unsur $\mathrm{N}$ dan $\mathrm{K}$, sehingga tidak mudah terbawa oleh aliran massa (Handayanto dkk, 2017). Kalau konsentrasi tinggi, ion P sulit bergerak. Mitra dkk (1999) membuktikan ketersediaan fosfor untuk kacang hijau dapat meningkatkan hasil kering panen, jumlah polong per tanaman, biji per polong, bobot 1000 butir, hasil biji dan biomassa total, sementara fiksasi P dalam tanah akan menurunkan hasil dan kualitas pertumbuhan tanaman kacang hijau. Sementara suplai fosfor dalam organ tanaman meningkatkan metabolisme dalam tanaman, terutama pada fase pengisian biji dapat meningkatkan berat biji (Hidayat, 2008). Unsur P lebih mudah diserap tanaman jika KTK tanah rendah, pada tanah-tanah dengan KTK sedang sampai tinggi terjadi fiksasi unsur P oleh koloid tanah yang didominasi tekstur tanahnya yang lempung berliat. (Handayanto dan Muddarisna, 2017). Hasil penelitian ini sejalan dengan penelitian Halomoan et al (2013) yang menunjukkan bahwa dosis POC $2 \mathrm{ml} /$ liter memberikan hasil terbaik terhadap jumlah cabang produktif dan berat biji kacang hijau dan berbeda dengan Lewar, dkk. 2020. Menunjukkan 4-8 ml/liter 
memberikan jumlah biji pertanaman kacang merah yang lebih banyak di bandingkan $2 \mathrm{ml} /$ liter.

Perlakuan 2-4 ml/liter air juga diduga memberikan suplai unsur $\mathrm{K}$ lebih baik dibandingkan perlakuan dengan konsentrasi yang lebih pekat. Unsur $\mathrm{K}$ adalah unsur yang sangat immobile sehingga kepekatan larutan menyebabkan $\mathrm{K}$ sulit diserap tanaman.Marzuki (2007) menyatakan tanaman yang mendapatkan unsur kalium yang cukup dapat memanfaatkan air dan hara secara efisien, baik yang berasal dari tanah dan pupuk, akan menghasilkan tanaman kacang-kacangan yang berkualitas baik, polong tumbuh baik dan berisi penuh.

Hasil biji perpetak juga dipengaruhi oleh interval aplikasi POC ABG yaitu interval aplikasi setiap 7 hari memberikan hasil biji perpetak tertinggi yaitu 240,66 gram. Hal ini disebabkan dengan interval 7 hari sekali maka frekwensi pemberian POC ABG lebih banyak. Dengan demikian unsure hara berada pada jumlah yang tersedia lebih banyak dan tersedia secara kontiniu sehingga dapat meningkatkan pertumbuhan dan hasil tanaman. Menurut Sumiati (1999) dalam Arham, dkk. 2014 ketersediaan pupuk baik yang mengandung unsur hara makro maupunmikro dalam keadaan cukup merupakan sumber nutrisi sebagai bahan yang mensuplai tanaman dalam bentuk mineral elemen penting.

\section{KESIMPULAN}

Berdasarkan uraian di atas, maka disimpulkan bahwa:

1. Konsentrasi dan interval aplikasi POC ABG tidak memberikan pengaruh terhadap jumlah biji dan berat 100 butir biji kacang hijau varietas lokal Sabu

2. Konsentrasi POC ABG 2 dan $4 \mathrm{ml} /$ liter air memberikan hasil biji perpetak tertinggi

3. Interval aplikasi POC ABG 7 hari sekali memberikan jumlah polong pertanaman, hasil biji pertanaman dan hasil biji perpetak tertinggi

4. Konsentrasi POC ABG $4 \mathrm{ml} /$ liter air dan interval aplikasi 7 hari sekali memberikan jumlah polong pertanaman dan hasil biji pertanaman tertinggi. 


\section{DAFTAR PUSTAKA}

Ali, M. A., Abbas, G., Mohy-ud-Din, Q., Ullah, K., Abbas, G., \& Aslam, M. 2010. Response of Mungbean (Vigna radiata) to phosphatic fertilizer under arid climate. Journal of Animal and Plant Sciences, 20(2), 83-86.

Arham, Samudin S., Maauna I., 2014. Frekuensi pemberian pupuk organik cair dan berbagai Jenis mulsa terhadap pertumbuhan dan hasil bawang Merah (allium ascalonicum 1.) Varietas lembah palu.e-J. Agrotekbis 2 (3): 237-248.

Azis A dan Bakar B. A. 2015. Teknologi Beberapa Varietas Kacang Hijau Pada Lahan Kering. BPTP NAD.

Dirjen tanaman Pangan Kementerian Pertanian. Laporan Tahunan. http:/sakip.pertanian.go.id, diakses 31 Oktober 2021.

Handayanto dan Muddarisna, 2017. Pengelolaan kesuburan tanah.UB Press.

Halomoan R. Sihotang, Dwi Zulfita, Ahmad M. Surojul (2013) Pengaruh Pupuk Organik Cair Terhadap Pertumbuhan Dan Hasil Kacang Hijau Pada Tanah Aluvial.https://www.neliti.com/id/journals/jurnal-sains-mahasiswa-perta nian-untan.

Handayanto dan Muddarisna, 2021. Pengelolaan Kesuburan Tanah. UB Press.

Hidayat, N. 2008. Pertumbuhan dan Produksi Kacang Tanah (Arachis hypogea L.) Varietas Lokal Madura Pada Berbagai Jarak Tanam dan Pupuk Fosfor. Agrovigor, Volume 1 No. 1. Hal: 55-64.

Kuntyastuti H dan Lestari Sri Ayu, 2016. Pengaruh Interaksi Antara Dosis Pupuk dan Populasi Tanaman Terhadap Pertumbuhan dan Hasil Kacang Hijau Pada Lahan Kering Beriklim Kering. Balai Penelitian Tanaman Aneka KAcang dan Umbi. Kendalpayak. Malang.

Lewar Y, Hasan A, Bunga J. A dan Vertigo, S. 2020. Pertumbuhan dan Hasil Kacang Merah Varietas Inerie di Dataran Rendah Akibat Pemberian Pupuk NPK dan Biostimulan Amazing Bio Growth.Jurnal Penelitian Pertanian Terapan Vol. 20 (3): 237-246.

Lidjang, I. K, Bora, C.Y dan Pohan A, 2012. Prospek dan Kendala Perbenihan Kacang-kacangan di Nusa Tenggara Timur. BPPT NTT. Prosiding Seminar Penelitian Tanaman Aneka Kacang dan Umbi. Kendalpayak. Malang.

Marzuki, R. (2007). Bertanam Kacang Tanah. Penebar Swadaya, Jakarta.

Mitra, S., S. K. Rhattacharya, M. Datta and S. Banik. 1999. Effect of variety, rock phosphate and phosphate solubilizing bacteria on growth and yield of green gram in acid soils of Tripura. Environmental Economics 17: 926-930. 
Muchlis, A. M dan Marwoto. 2011. Inovasi Teknologi Unggulan Tanaman Kacang-kacangan dan Umbi-umbian Mendukung Empat Sukses Kementerian Pertanian. Prosiding Seminar Penelitian Tanaman Aneka Kacang dan Umbi. Kendalpayak. Malang.

Murdelelono, B. 2011. Teknologi Kacang-kacangan Untuk Petani Nusa Tenggara Timur. BPTP NTT. Prosiding Seminar Penelitian Tanaman Aneka Kacang dan Umbi. Kendalpayak. Malang.

Theodore M. E. and W. C Plaxton. 1993. Metabolic adaptations of plant respiration to nutritional phosphate deprivation. Plant Physiol. 101: 339-34. 